Lauster Housing and the Proper Performance of American Motherhood, 1940-2005

\title{
Housing and the Proper Performance of American Motherhood, 1940-2005
}

\author{
Nathanael Lauster \\ Sociology Department, University of British Columbia
}

Post-print version of:

Lauster, Nathanael. 2010. Housing and the Proper Performance of American Motherhood, 1940-2005.

Housing Studies 25(4): 543-557. DOI: 10.1080/02673031003711485

\begin{abstract}
Current approaches to the link between family and housing tend not to closely examine cultural change. In this paper I attempt to provide a theoretical framework, rooted in symbolic interaction, dramaturgy, and critical theory, well-suited to the study of cultural change. I apply this critical dramaturgical framework to explore the changing link between housing as a stage prop and the privileged performance of motherhood. I argue that redefinition of the proper performance of motherhood by the privileged constitutes an important aspect of cultural change, making positive evaluations of motherhood more difficult to achieve without a proper house. This results in an increase in stage fright, or women avoiding motherhood because they feel ill prepared to perform it properly, and an increase in the devaluing of certain categories of mother. I use US census data collected through the IPUMS project to provide evidence of these trends, where available, and suggest further avenues of research.
\end{abstract}

Keywords: culture, fertility, family, home ownership, housing choice, social theory 
Lauster Housing and the Proper Performance of American Motherhood, 1940-2005

Why are housing transitions linked to family transitions? There are explanations for links grounded in the rational choice language of underlying preferences and constraints (Clark, et al, 1997; Lauster \& Fransson, 2006; Mulder \& Wagner, 1998, 2001). Here family formation either operates directly upon preferences and constraints for housing (Lauster \& Fransson, 2006; Mulder \& Wagner, 2001), or housing operates as a constraint upon family formation (Hughes, 2003; Lauster, 2006; Mulder, 2006). There are also vague cultural reasons to expect different types of links, grounded, for instance, in sweeping claims about the importance of the Northwest European pattern of family formation relative to alternatives (Hajnal, 1965, 1982; Hughes, 2003; Lauster, 2002; Lauster, 2006). Overall, these links tend to assume either that culture remains relatively static, or that cultural change acts as an externality upon the relationship between housing and family formation.

Here I explore a different possibility. I am interested in quantitatively exploring endogenous models of cultural change. In particular, I suggest that cultural change might operate through the changing link between family formation and housing. I propose building a critical dramaturgical framework for the study of cultural change rooted in symbolic interaction and conflict theory to explore this issue.

\section{A New Framework for Study}

The first step in building a framework for the study of cultural change is to accept that the categories we use to describe housing and family are both symbolically constituted and socially evaluated (Mead, 1964). I assume being assigned into categories: mother, father, spouse, homeowner, etc., is meaningful to people and bestows social value (Ridgeway, 1991; Tilly, 1999). Yet I don't assume the meaning and value of being assigned into different categories remains the same. Instead, meaning and value responds to social context.

I next assume that the social context determining meaning and value responds to power. As outlined by Tilly (1999), the privileged may strategically shape the meaning and value of different categories so as to provide themselves status and hence justify their own social advantage. As outlined by Ridgeway (1991), the process of differential symbolic evaluation favoring the privileged can also occur in various contexts without conscious strategizing. Differences in the way symbols adhere to the privileged and the marginalized are often enough to bestow symbols with meaning and value. Ridgeway focuses on how this process differentially values masculinity in the workplace, bestowing value on being a man simply because most people in power are men (Ridgeway, 1991). Power imbalances coupled with symbolic differences tend to imbue the symbols attached to the powerful with disproportionate value. So overall, building upon both Tilly (1999) and Ridgeway (1991), as well as Bourdieu (1984) and Lamont (1992), I assume that strategic incentives are in place driving the privileged to symbolically distinguish themselves from the less advantaged. The status they derive from symbolic distinction helps justify their entitlements.

Categories for housing and family, then, are likely to take on differential status value according to how they are used by the privileged to distinguish themselves. For instance, ownership, marriage, and parenthood might all be high status categories if these roles come to categorize those with power, likewise differentiating those with power from the socially marginalized. These assumptions provide a basis for understanding how power interacts with the symbolic basis for social interaction, but they don't yet provide a clear link between family status and housing status. 
Lauster Housing and the Proper Performance of American Motherhood, 1940-2005

To better establish this link, I turn to Goffman's dramaturgical framing. Goffiman (1959) builds upon Mead's symbolic interactive perspective by considering how people create symbolic boundaries in everyday life. Much as in a play, Goffman casts everyday life in terms of performance. Symbols become roles, like spouse, parent, and homeowner, which are all performed. The performance of roles, in turn, grants status value, with performances receiving positive evaluations granting higher status, while performances receiving negative evaluations detract from status. According to role theory, holding multiple roles may be troublesome, creating role strain as one attempts to perform for multiple, at times competing audiences (Turner, 1956). Yet crucially, holding multiple roles can also provide greater status (Sieber, 1974). In effect, one role can serve as a stage prop for another, supporting the performance. Ethnographies, like Townsend's study of middle class fatherhood, demonstrate how the proper performances of roles like father, worker, husband, and home owner all depend upon one another (Townsend, 2002).

In the process of discussing social performance, Goffman also demonstrates the importance of staging. He delineates front stage, where one performs for an audience, from backstage, where one prepares performances (Goffman, 1959). The division into front stage and backstage is context specific and audience-dependent. When one actor brings another backstage, making them complicit in the preparation of a performance, it can demonstrate trust and familiarity, but it can also be part of just one more performance.

In this dramaturgical setting, family situations are comprised of roles (e.g. husband, wife, mother, father, child) which become performed, both for a familial audience, and a wider social audience (at which point the familial audience becomes complicit in creating a performance). One role (e.g. wife) can easily become a stage prop for the proper performance of another (e.g. mother). Housing situations, like family situations, also create roles (e.g. tenant, home owner) which may also become stage props for the proper performance of other roles. Yet housing also serves as a corporeal symbol and a physical stage upon and within which family roles are performed.

The dramaturgical metaphor is meant to convey the idea that family roles and housing roles, stage props, and housing context as stage manifest, all work together in the context of the social production of performance. Good performances provide social status. Bad performances result in social marginalization. Those with power possess differential ability to bestow status, and those with power tend to shape the context for evaluation of social performances. Through various means, the powerful create privileged status categories, which they also tend to occupy (see Frykman \& Löfgren, 1987, for an example of this process). The privileged also serve as role models for proper performance of social roles, including the intimate familial roles of parent and spouse, as well as the propertied role of home owner. As mentioned earlier, those with power have incentive to distinguish their performances from the marginalized, justifying their relative social advantage. The powerful are driven by their position to innovate new ways of maintaining the social distinction of the privile ged positions they occupy. Yet, at least in egalitarian legal settings, this dynamic creates incentive for the masses to emulate the performances of the privileged, both as a route to social advancement, and as a moral imperative (Lamont, 1992; Ridgeway, 1991). Where actors find themselves unable to meet the proper performance standards of social roles as defined by the privileged, due to a lack of requisite stage props or poor staging, they may respond in two ways. They can either avoid taking on the role (succumbing to stage fright) or they can go ahead and attempt the role despite their lack of proper preparation. In the latter 
Lauster Housing and the Proper Performance of American Motherhood, 1940-2005

case, they are likely to face significant negative attention until or unless they alter their performance, bringing it in line with those properly prepared. Hence actors must either comply with performance standards, or be forced to experience social stigmatization. In this, dramaturgical theory evokes social norms. The performances of the privileged role model the expected behavior for the population as a whole, operating as a prescriptive norm (Kemper, 1968; Marini, 1984; Townsend, 2002). Overall, the critical dramaturgical framework described here directs attention towards how inequality serves as an engine of privilege-led cultural change, which in turn directs the drama of daily life.

\section{Empirical Investigation}

Dramaturgical theory, as well as most other theories based in symbolic interaction, have been dominated by qualitative research, which is likely one reason they have been less often explored in demography. Yet as I attempt to demonstrate below, the framework I discuss above is amenable, and even friendly to quantitative description and analysis. I use US census data from the IPUMS project (Ruggles, et al 2004) to provide information about historical change in the United States in the way the privileged and the non-privileged perform family roles. Here I focus in particular on the crucial role of motherhood, and how it has become linked to housing roles and stage materials. I choose to focus upon motherhood for its obvious and easily measurable connections to fertility, but focusing on other roles involved in the family formation process, like husband, father, or wife, could also be accomplished with little difficulty.

The US IPUMS data contains historical census records collected from 1850-2005. Here I focus on the data from 1940 through 2005, since this data provides crucial information about income and housing characteristics unavailable in earlier years. Recognizing that racialization constitutes its own form of symbolic distinction, with a changing legacy for the social evaluation of the performance of family roles, I narrow down the range of symbolic differences for this paper by focusing on the non-Hispanic, white population of women. Since I focus on fertility, I further narrow down the range of women to those age 15-45.

Adopting a critical dramaturgical framework which pays attention to privileged performances of motherhood first requires a way to define the privileged so as to understand how they might perform roles differently from the rest of the population. Here I adopt a definition of the privileged based in the context of capitalism. I use family income as a proxy for the power that mothers can bring to bear upon the social context of performances. Some measure of family income is available from 1940 onward in the census, serving as a baseline for the current study. I assume that family income provides power distributed at the discretion of household heads and spouses or partners. For those mothers who are not the head of a household or a spouse or partner, I use their personal income rather than their family income (which might also include, for instance, a parent's income for mothers living with a parent). Family income is also relative, so that I assume women in the top $10 \%$ of the family income distribution will be able and willing to mobilize resources in such a way as to distinguish their own role performances from those performances found in the population as a whole. While the top 10\% is an arbitrary cut-off, it allows a comparison with the historical research on income inequality by Picketty \& Saez (2001), and it defines a proportionately constant set of privileged people for historical study. I also assume that the privileged are locally constituted here. Hence the top $10 \%$ family income cut-off for defining the privileged is measured by metropolitan area (for the population living in metro areas) or non-metropolitan state (for the non-metro population). After defining who is included as privileged, the 
Lauster Housing and the Proper Performance of American Motherhood, 1940-2005

next task is to measure how their performances of the role of motherhood tend to differ from the population as a whole. The average local family income cut-off defining mothers as being in privileged households varies between years as follows:

Table one. Average Local Family Income Cut-Offs Defining Privileged Mothers

\begin{tabular}{l|l|l|l|l|l|l|l}
$\mathbf{1 9 4 0}$ & $\mathbf{1 9 5 0}$ & $\mathbf{1 9 6 0}$ & $\mathbf{1 9 7 0}$ & $\mathbf{1 9 8 0}$ & $\mathbf{1 9 9 0}$ & $\mathbf{2 0 0 0}$ & $\mathbf{2 0 0 5}$ \\
\hline$\$ 2,404$ & $\$ 5,334$ & $\$ 11,500$ & $\$ 18,548$ & $\$ 40,131$ & $\$ 77,155$ & $\$ 119,397$ & $\$ 159,156$
\end{tabular}

In order to understand how the privileged performance of motherhood might have changed, it is desirable to look at the various roles and symbols likely to serve as stage props for the proper performance of motherhood. When these roles and symbols regularly and reliably appear together with motherhood for the privileged, they become normative, defining privileged performances. I use a somewhat arbitrary cut-off for defining when roles and symbols take on normative stage prop properties. When $80 \%$ or more of privileged mothers share a role or symbolic identification, I define this as normative for privileged performances.

I argue that the strategic search for distinction serves as a force behind the privileged population adding new symbolic elements to their normative performances. The distinction provided by stage props drives more privileged people (and those aspiring to privilege) to adopt those stage props into their own performances. As more people adopt the same stage props as the privileged for their performances, the distinctive value of a stage prop wanes, even as the normative sanctions attached to its performance value rise. In this way, some privileged norms spread to become universally adopted, supported by widespread social sanctions. For example, the presence of a breadwinning spouse became seen as a necessary stage prop for the proper performance of motherhood in the US, as derived from historical and ethnographic literature (Edin \& Kefalas, 2005; Gillis, 1996; Hays, 1996; Townsend, 2002). Yet the ability of people to adopt the same stage props as the privileged also changes over time, responding to social inequality. Hence some stage props retain their distinctive value as they remain out of reach for many, even most non-privileged people.

Fortunately, measurements relating to the stage propping of role performances, like motherhood, can be derived from the census. The presence of a breadwinning spouse, for instance, can be measured with marriage and employment data from at least 1880 onward. The census also has relatively rich data on housing, especially from 1960 onward. Townsend (2002) provides ethnographic evidence for the 1990s that home ownership serves as an important stage prop for proper performance of fatherhood, likely carrying over to motherhood as well. Ownership is measurable in the 1900-1940 census collection and from the 1960 census onward.

Aspects of the house which might possibly serve as physical stage propping for the proper performance of motherhood include whether or not the house is detached (providing the possibility for the proverbial "white picket fence"), whether or not the house is roomy, and how many bathrooms the house has. All of these features of the house serve both as staging matter setting up the performance of proper family life for the wider social world outside of the family, and as staging matter dividing up performance space within the family into adequate front stage and backstage space (Aragones, 2002; Frykman \& Löfgren, 1987). A measure of the structure of current housing (measuring whether or not it is a 
detached, single-family dwelling) is available from 1960 onwards. A measure of how many rooms a house contains (not counting bathrooms) is also available from 1960 onwards. For purposes of this analysis, I treat housing with six (6) or more rooms as being roomy, hence including room for a master bedroom, at least one children's bedroom, a kitchen, living room, dining room, and den. A measure of the number of bathrooms for a housing unit is available from 1960 to 1980. I separate out those housing units having at least two bathrooms as distinct. I also explored a variety of other features of housing that might constitute important stage material for the performance of motherhood for this analysis, including the newness of housing, the number of stories in a structure, and other variables. Unfortunately, these other features of housing were either measured poorly in the census, or were found to be relatively unimportant in the analysis.

In table two, I look only at privileged mothers of new infants (where the youngest child in the household is less than one year old). This provides insight into the staging conditions under which women in privileged households feel ready to perform motherhood. Notably, being married to a breadwinning spouse (one who is actively employed) remains normative to the privileged for performances of motherhood for all years between 1940 and 2005. Strikingly, housing symbols and roles are not normative parts of the performance of motherhood for anyone in 1940. They gradually become more and more representative of privileged performances in the post-war years. By 1970, living in a detached, single family house becomes normative for privileged mothers. By 1980, owning one's own home also becomes normative, in addition to living in a roomy house (6+ rooms) and having at least two bathrooms. Once these stage props are added to the list of prerequisites for proper performance of privileged motherhood, they never again slip below $80 \%$.

Table Two. Percent of Privileged Mothers by Representation of Stage Props, Non-Hispanic White Women 15-45

\begin{tabular}{lrrrrrrrr} 
& 1940 & 1950 & 1960 & 1970 & 1980 & 1990 & 2000 & 2005 \\
\cline { 2 - 8 } Married & $\mathbf{1 0 0 \%}$ & $\mathbf{1 0 0 \%}$ & $\mathbf{1 0 0 \%}$ & $\mathbf{1 0 0 \%}$ & $\mathbf{9 9 \%}$ & $\mathbf{1 0 0 \%}$ & $\mathbf{1 0 0 \%}$ & $\mathbf{9 9 \%}$ \\
Breadwinner & $\mathbf{9 8 \%}$ & $\mathbf{9 7 \%}$ & $\mathbf{9 9 \%}$ & $\mathbf{9 8 \%}$ & $\mathbf{9 8 \%}$ & $\mathbf{9 8 \%}$ & $\mathbf{9 7 \%}$ & $\mathbf{9 6 \%}$ \\
Owner & $39 \%$ & $* 58 \%$ & $78 \%$ & $78 \%$ & $\mathbf{9 0 \%}$ & $\mathbf{9 2 \%}$ & $\mathbf{9 2 \%}$ & $\mathbf{9 5 \%}$ \\
Detached & & & $67 \%$ & $\mathbf{8 4 \%}$ & $\mathbf{8 7 \%}$ & $\mathbf{8 8 \%}$ & $\mathbf{8 7 \%}$ & $\mathbf{9 0 \%}$ \\
Roomy & & & $66 \%$ & $70 \%$ & $\mathbf{8 1 \%}$ & $\mathbf{8 6 \%}$ & $\mathbf{8 7 \%}$ & $\mathbf{8 8 \%}$ \\
Multi-Bath & & & $44 \%$ & $67 \%$ & $\mathbf{8 1 \%}$ & & &
\end{tabular}

Bold denotes normative

* denotes interpolated percentage

I argue that the privileged search for distinction drives the addition of new stage props into the privileged performance of motherhood. In chart one, below, I chart the difference between the percent of the privileged (the top income decile) holding different stage props, and the percent of the most marginalized (the bottom income decile) holding different stage props. Strikingly, the difference between the top income decile and the bottom income decile was not great in 1940. Being married to a breadwinning spouse was part of the normative criteria for childbearing for women at both the top and 
Lauster Housing and the Proper Performance of American Motherhood, 1940-2005

the bottom of the family income distribution. Ownership was not representative of women at either the top or the bottom, with $39 \%$ of privile ged mothers owning their own houses, and $23 \%$ of the most marginalized mothers owning their own houses. Using ownership as a criterion distinguishing between the privileged and the most marginal in 1940 would provide a correct guess only $58 \%$ of the time, scarcely more often than random chance. But ownership became rapidly more distinctive during the Baby Boom years following WWII. By 1990, using ownership as a criterion distinguishing the privileged from the marginal would provide a correct guess well over $90 \%$ of the time. The rising importance of ownership as a distinctive symbol separating successful and privileged mothers from socially marginalized mothers made it increasingly important for most women to become owners before taking on the role of motherhood. Other characteristics of housing, measured from 1960 onward, show similar signs of becoming increasingly important as sources of symbolic distinction, explaining in part the rise in the proportion of the privileged becoming the owners of detached, roomier houses with at least two bathrooms.

Of note, the universal importance of having a breadwinning spouse in 1940 remained roughly constant for the privileged in later years, but declined for mothers in the bottom income decile. By 1950, it was no longer normative for this group, with less than $80 \%$ of new mothers in the bottom decile being attached to breadwinning spouses. By 2005, having a breadwinning spouse for mothers in the lowest income decile became quite rare, with fewer than $20 \%$ of low income mothers reporting this stage prop for the proper performance of motherhood.

[Chart One About Here]

Notably, there is also historical variation in the stage propping of first motherhood relative to subsequent motherhood. As summarized in table two, privileged mothers having their firstborn child faced slightly less stringent normative housing-related requirements than other privileged mothers. The assumption being, presumably, that they would quickly catch up to the proper housing staging, as demonstrated by other privileged mothers, before having further children. Nevertheless, for 1970-1990, this meant mothers of first born children, or new entry into motherhood, may have faced slightly less stringent standards than mothers continuing on to higher parity births. Intriguingly, the symbolic differences between first motherhood and higher order motherhood tend to diminish over time, indicating that the notion of stage props as co-requisites of privileged motherhood, obtainable shortly after giving birth, may have been replaced by the notion of stage props as pre-requisites of motherhood.

Table Three. The Difference between All Privileged Mothers of Newborns and Privileged Mothers of Firstborn Newborns in Representation of Stage Props, Non-Hispanic White Women Age 15-45.

\begin{tabular}{lrrrrrrrr} 
& 1940 & 1950 & 1960 & 1970 & 1980 & 1990 & 2000 & 2005 \\
\cline { 2 - 8 } Married & $\mathbf{0 \%}$ & $\mathbf{0 \%}$ & $\mathbf{0 \%}$ & $\mathbf{0 \%}$ & $\mathbf{0 \%}$ & $\mathbf{0 \%}$ & $\mathbf{0 \%}$ & $\mathbf{0 \%}$ \\
Breadwinner & $\mathbf{- 1 \%}$ & $\mathbf{0 \%}$ & $\mathbf{1 \%}$ & $\mathbf{0 \%}$ & $\mathbf{1 \%}$ & $\mathbf{0 \%}$ & $\mathbf{- 1 \%}$ & $\mathbf{- 1 \%}$ \\
Owner & $10 \%$ & $* 15 \%$ & $20 \%$ & $14 \%$ & $\mathbf{2 \%}$ & $\mathbf{3 \%}$ & $\mathbf{0 \%}$ & $\mathbf{1 \%}$ \\
Detached & & & $17 \%$ & $\mathbf{1 4 \%}$ & $\mathbf{7 \%}$ & $\mathbf{7 \%}$ & $\mathbf{2 \%}$ & $\mathbf{6 \%}$ \\
Roomy & & & $23 \%$ & $19 \%$ & $\mathbf{7 \%}$ & $\mathbf{8 \%}$ & $\mathbf{4 \%}$ & $\mathbf{7 \%}$ \\
Multi-Bath & & & $15 \%$ & $11 \%$ & $\mathbf{4 \%}$ & & &
\end{tabular}


The addition of stage props to the performance standards for performing motherhood properly have coincided with historical changes in access to stage props. In particular, access to proper housing became more tenuous at approximately the same time that it became an important stage prop in the proper performance of motherhood. In chart two, I demonstrate the changes in access to ownership, as measured by income, 10-year composite mortgage rates (Homer \& Sylla, 1991), and median local housing value. Roughly speaking, access to ownership is measured as being able to make the estimated 30 -year mortgage payment for the median local housing value using less than $25 \%$ of income. In general, access to ownership rose to a peak in 1960 and 1970, then dropped sharply in 1980, just as it became a normative aspect of the performance of motherhood for those with privilege. Despite becoming a normative aspect of the proper performance of motherhood, ownership never became as affordable after 1980 as it had been before 1980. Not inconsequentially, extra incomes became more important for securing familial access to ownership from 1980 onward.

[Chart Two About Here]

In chart three, I explore how financial access to ownership affects actual ownership. As ownership becomes more important and begins acting as a stage prop for the proper performance of motherhood, those who can and those who cannot afford ownership all become more likely to own. Just $35 \%$ of those who could afford the estimated median cost of a mortgage on a single income took on ownership in 1940 , contrasting with $91 \%$ in 2005 . Even more striking in this chart is that prior to 1980 , those who could afford home ownership on a dual income, but not on a single income, were unlikely to take on ownership. From 1980 onwards, just as the earlier table demonstrated that ownership took on normative power for the privileged, families that could only afford ownership with two incomes became increasingly likely to take on ownership. This provides further support that ownership became a part of the normative performance of privileged motherhood by 1980, and the importance of being a stay-athome mother became increasingly outweighed by the importance of owning a home (Edwards, 2001).

[Chart Three About Here]

So far I've mostly described the changing context for the privileged performance of motherhood, linking the rise of new normative elements of the staging of motherhood to the distinctive value they provide for privileged mothers. But I argue that there are implications of this cultural change. The historically changing performance standards for motherhood, especially as they incorporate housing into the staging of proper motherhood, can affect the overall fertility of women and the stigmatization of new classes of mothers. I will begin by concentrating on the effects on fertility.

I argue that higher performance standards for motherhood, often in conjunction with lower abilities to meet those performance standards, can create a sort of stage fright, motivating women to avoid taking on the role of mother if they don't think they'll be able to perform it properly. In chart four, below, I compare the percent of all Non-Hispanic White women, ages 15-45, with the proper stage props (derived from table two) for performing motherhood (both first-time motherhood and all motherhood) 
Lauster Housing and the Proper Performance of American Motherhood, 1940-2005

with a census-derived estimate of the Total Fertility Rate. I estimate the TFR by using the presence of children under age one as the basis for generating age-specific rates of childbearing. This provides a slight underestimate of fertility by ignoring infant mortality, but otherwise generates a broadly comparable figure for fertility across census years. Strikingly, the broad pattern of the percent of women with proper stage props for motherhood (and the slightly less stringent proper stage props for first-time motherhood) corresponds well with the pattern of observed TFR between 1940 and 2005. This provides correlational evidence that stage fright may be motivating women to postpone or forego childbearing.

\section{[Chart Four About Here]}

Another way to understand the possible impact of stage fright on fertility is to estimate separate total fertility rates for those with the proper stage props for motherhood in each year, and for those without the proper stage props for motherhood. This would provide some evidence bearing upon how the total fertility rate moves between these two figures. Presumably the controlling feature bearing upon movement between these two figures is the average number of years spent with the proper stage props for motherhood. I can summarize this for each year in a similar way to the method for obtaining an estimate of TFR. For each age, I summarize the proportion of women with the proper stage props for motherhood. Totaling this proportion across all ages provides an estimate of the number of years between age 15 and 45 the averaged women is likely to possess the stage props for the proper performance of motherhood. Chart five summarizes these figures.

Chart five makes clear that variation in childbearing between census years is not entirely determined by stage propping as defined here. Fully stage propped TFR ranges widely between years, climbing during the Baby Boom, and dropping precipitously through the 70s and 80s before rising again in the 90s. Unstaged TFR climbs between 1940 and 1970, before leveling off at a slightly lower level in subsequent years. The rise in unstaged TFR, in particular, might reflect a decline in the power of social norms to govern youth behavior, as suggested by Rosenfeld (2006). Regardless, the stage propping shifts discernible through census data do not explain the historical variation in TFR within groups (staged and unstaged), though other changes in performance standards might. However, stage propping is quite helpful in tying variation between the staged and unstaged to overall variation in TFR. Noticeably in chart five, as the number of years the average woman is likely to possess the stage props for the proper performance of motherhood rises, the closer the TFR figure approximates the TFR for women with stage props, which remains always far above replacement level. As the number of years the average woman is likely to possess the stage props for the proper performance of motherhood drops from 1970 onward, the more the TFR figure approximates the TFR for women without stage props, which remains always below replacement level.

[Chart Five About Here]

If one implication for the changing standards of the performance of proper motherhood is stage fright, the other is slightly more complicated, involving the rise in negative evaluations of the performance of motherhood. Those women who decide to have children despite lacking the stage props which would assist them in performing motherhood properly are likely to receive negative reviews of their 
performances. For those women aspiring to perform motherhood properly, this can be a powerful impetus driving their residential choice. For other women, often lacking any means to attain the stage props of proper motherhood, having a child is likely to become an act of resistance and contestation, generating significant negative attention.

In chart six, below, I attempt to summarize the likely experiences of the average woman for each census year with respect to motherhood status and stage prop status. Again, the method I employ is to sum the rates of exposure to each status for each year of age. In this case, I look to explore how many women are avoiding performing motherhood (likely experiencing stage fright, or feeling unprepared), how many women are performing motherhood despite lacking the stage props, how many women possess the stage props without performing motherhood, and how many women are performing motherhood in the same fashion as the privileged. Over time, especially as new, increasingly difficult to afford stage props are added to the criteria determining the proper performance of motherhood, more women spend more of their lives without children or facing possible contestation in their performances of motherhood.

Women tend to spend less of their time prepared for motherhood without following through and actually performing the role. A decreasing amount of time is spent secure in the exemplary performance of proper motherhood.

[Chart Six About Here]

\section{Implications}

In this paper I offer a new framework for approaching the link between family and housing. This framework assumes that actors attempt to stage and perform family roles and housing roles in ways likely to receive positive evaluations. Symbols and performances that provide privileged status become linked to the powerful, who have incentive to distinguish their performances from others, who in turn have incentive to emulate the privileged. In this way social inequality generates privilege-led cultural change. The framework provides insights into the way privilege-led cultural change tends to react to social inequality, increasing the symbolic exclusion of the economically marginalized while socially enshrining the advantages of the privileged. At the same time, the framework predicts and explains a growing link between housing roles, like ownership, housing characteristics, like structure and size, and family roles, like motherhood. Ownership of detached, roomy houses becomes an important stage prop for the proper performance of motherhood.

Here I focus on the role of housing in redefining upward the role of motherhood, but I do not mean to imply that housing is the only way motherhood is experiencing cultural change. While the relationship between housing and motherhood has received relatively little scholarly attention (as opposed to housework), other scholars have noted the upward redefinition and idealization of motherhood in other ways. Hays (1996), for instance, notes the rise of an ideology of intensive motherhood by which mothers must identify and define their own performances.

Here I argue that as motherhood becomes more difficult to perform properly, women spend less of their childbearing years taking on the role. I have termed this a form of stage fright, or an unwillingness to take on a role without preparing to be able to perform the role like the privileged. For many women, not being able to purchase an appropriately child-friendly home increasingly means postponing or foregoing 
Lauster Housing and the Proper Performance of American Motherhood, 1940-2005

motherhood. Since 1980, at the same time ownership became particularly important for the privileged performance of motherhood, it also became more expensive, further depressing the willingness of women to become mothers. I provide evidence that the same cultural change which likely depressed fertility from at least 1980 onward also seems to have elevated the importance of the working mother, whose income became increasingly important to afford proper housing.

Yet the decrease in fertility and rise of the dual income family are not the only implications of upwardly defining the proper performance of motherhood. There always have been, and will continue to be women who take on the role of motherhood despite the lack of privileged stage props. These women provide a challenge to the privileged performance of motherhood, and are met with societal disapproval. Edin \& Kefalas (2005) provide examples of the stigma single mothers face. Lareau (2003) provides further examples of how the performance of working class motherhood is judged harshly by institutions like schools. Miron (1993) and Perin (1977) provide examples of how policy makers decide what is appropriate and inappropriate housing for raising children. The theoretical framework applied here predicts which mothers are likely to meet with social disapproval at which time and place. It is incumbent upon scholars to recognize the way inequality shapes performance standards to the disadvantage of the socially marginalized. Rather than further contributing to the stigmatization of marginal performances of motherhood, scholars should strive to better understand the conditions that devalue mothers and children with less power to shape cultural ideas of what is and is not appropriate.

While the theoretical framework developed and applied here has important and substantive implications for studying the interrelationships of family roles and housing, much work remains to be done. Qualitatively, more work would be useful to understand how people think about the relationships between housing and family formation. What narratives do they use to link motherhood to housing? Is there an understanding that good mothers do not attempt to raise their children in certain forms of housing (e.g. projects, tall apartment buildings, urban neighborhoods, etc.)? Are there aspects of the staging of motherhood clearly not captured by the census? The question of who produces what narratives linking motherhood to housing become particularly important. Quantitatively, more work can also be done. Most of the analyses here are descriptive and correlative in nature. Further analyses seeking to better define causal relationships within the context of endogenous models of cultural change could be helpful. Picketty and Saez (1998) document the decline and rise of income inequality surrounding the Baby Boom era. Does the degree of inequality affect the engine of cultural change specified here? If so, how? More longitudinal models could explore the trajectories relating mothering to housing across the life course to see how long unstaged periods last. Better historical models could address and attempt to measure the changing influence of access to housing as a stage prop of motherhood upon actual transitions to motherhood. Likewise, better models could address and attempt to measure the changing influence of becoming a mother upon making housing transitions. Importantly, the current paper provides evidence of why scholars should expect this relationship to change rather than remaining constant.

Overall, this paper attempts to provide a framework for analysis wherein housing and family roles take on real, and substantive meaning to people within the context of social inequality. Meaning and social inequality are often (though not always) missing from other theoretical frameworks, leaving researchers less able to provide deep insights into ongoing cultural changes. It should not be considered inconsequential that a baby means social fulfillment and an elevation in status for some people, while 
Lauster Housing and the Proper Performance of American Motherhood, 1940-2005

meaning a new round of criticism and social stigmatization for others, especially when whether a baby arrives in a house or rented apartment might contribute to its reception. 
Lauster Housing and the Proper Performance of American Motherhood, 1940-2005

\section{Bibliography}

Aragones, Juan Ignacio (2002) “The Dwelling as Place: Behaviors and Symbolism." Residential Environments: Choice, Satisfaction, and Behavior. Ed. I. Aragones, G. Francescato, and T. Gärling. Pp. 163-182.

Bourdieu, Pierre (1984) Distinction: A Social Critique of the Judgement of Taste. Cambrige, MA: Harvard University Press.

Clark, W. A. V., M. C. Deurloo, F. M. Dieleman (1997) "Entry to Home-ownership in Germany: Some Comparisons with the United States." Urban Studies 34(1): 7-19.

Dally, Ann (1982) Inventing Motherhood: The Consequences of an Ideal. London: Burnett Books. Edin, Kathryn \& Maria Kefalas (2005) Promises I Can Keep: Why Poor Women Put Motherhood Before Marriage. Berkeley: U.C. Press.

Edwards, Mark Evan (2001) 'Home Ownership, Affordability, and Mothers' Changing Work and Family Roles.” Social Science Quarterly 82(2): 369-383.

Frykman, Jonas and Orvar Löfgren (1987) Culture Builders: A Historical Anthropology of Middle Class Life. Translated by Alan Crozier. New Brunswick, NJ: Rutgers University Press.

Garey, Anita Ilta (1999) Weaving Work and Motherhood. Philadelphia: Temple University Press.

Gillis, John R. (1996) A World of Their Own Making: Myth, Ritual and the Quest for Family Values. Cambridge, MA: Harvard University Press.

Goffman, Erving (1959) The Presentation of Self in Everyday Life. New York: Anchor Books.

Hajnal, John (1965) "European Marriage Patterns in Perspective." Population in History. Ed. D. Glass \& D. Eversley. London.

Hajnal, John (1982) "Two Kinds of Preindustrial Household Formation System." Population and Development Review 8(3): 449-494.

Hays, Sharon (1996) The Cultural Contradictions of Motherhood. New Haven, CT: Yale University Press.

Hughes, Mary Elizabeth (2003) "Home Economics: Metropolitan Labor and Housing Markets and Domestic Arrangement in Young Adulthood." Social Forces 81(4): 1399-1429.

Kemper, T. (1968). "Reference groups, socialization, and achievement." American Sociological Review, 33: 31-45.

Lamont, Michelle (1992) Money, Morals, and Manners. Chicago: University of Chicago Press. 
Lauster Housing and the Proper Performance of American Motherhood, 1940-2005

Lareau, Annette (2003) Unequal Childhoods: Class, Race, and Family Life. Berkeley, CA: University of California Press.

Lauster, Nathanael (2002) "Hem Ljuva Hem: Cohabitation, Marriage, and Access to Home Ownership in Sweden, 1972-1992.” Scandinavian Population Studies 13: 171-190.

Lauster, Nathanael (2006) "A Room of One's Own or Room Enough for Two? Housing and Leaving Home for Family and Non-Family Destinations in Sweden, 1968-1992." Population Research and Policy Review 25(4): 329-351.

Lauster, Nathanael and Urban Fransson (2006) "Of Marriages and Mortgages: The Second Demographic Transition and the Relationship between Marriage and Home Ownership in Sweden." Housing Studies 21(6): 911-929.

Marini, M. (1984). "Age and sequencing norms in the transition to adulthood." Social Forces, 63: 229244.

Mead, George Herbert (1964) On Social Psychology. Chicago: University of Chicago Press.

Miron, J. (1993) House, Home, and Community: Progress in Housing Canadians, 1945 -1986. Montreal: McGill-Queen's University Press.

Mulder, Clara \& Michael Wagner (1998) 'First-time Home Ownership in the Family Life Course: A West German-Dutch Comparison.’ Urban Studies 35(4): 687-713.

Mulder, C. \& M. Wagner (2001) "The Connections between Family Formation and First-time Home Ownership in the Context of West Germany and the Netherlands." European Journal of Population 17: 137-164.

Mulder, C. (2006) "Home-ownership and family formation." Journal of Housing and the Built Environment 21 (3): 281-298.

Perin, Constance (1977) Everything in Its Place: Social Order and Land Use in America. Princeton University Press.

Piketty, T. and E. Saez (2001) 'Income Inequality in the United States, 1913-1998." NBER working paper 8467.

Ridgeway, Cecilia (1991) “The Social Construction of Status Value.” Social Forces 70(2): 367-386.

Ruggles, Steve, Matthew Sobek, Trent Alexander, Cathy Fitch, and Chad Ronnander (2004)

"Integrated Public Use Microdata Series: Version 3.0." http://www.ipums.prg.

Sieber, SD (1974) "Toward a Theory of Role Accumulation." American Sociological Review 39(4): 567-578.

Tilly, Charles (1999) Durable Inequality. Berkeley: University of California Press. 
Lauster Housing and the Proper Performance of American Motherhood, 1940-2005

Townsend, Nicholas (2002) The Package Deal: Marriage, Work and Fatherhood in Men's Lives. Philadelphia: Temple University Press.

Turner, Ralph (1956) 'Role-Taking, Role Standpoint, and Reference-Group Behavior." The American Journal of Sociology 61(4): 316-328. 
Chart One. The Distinctive Value of Stage Props as the Difference between their Representation for the Top Income Decile of Mothers and the Bottom Income Decile of Mothers, Non-Hispanic White Women Age 15-45

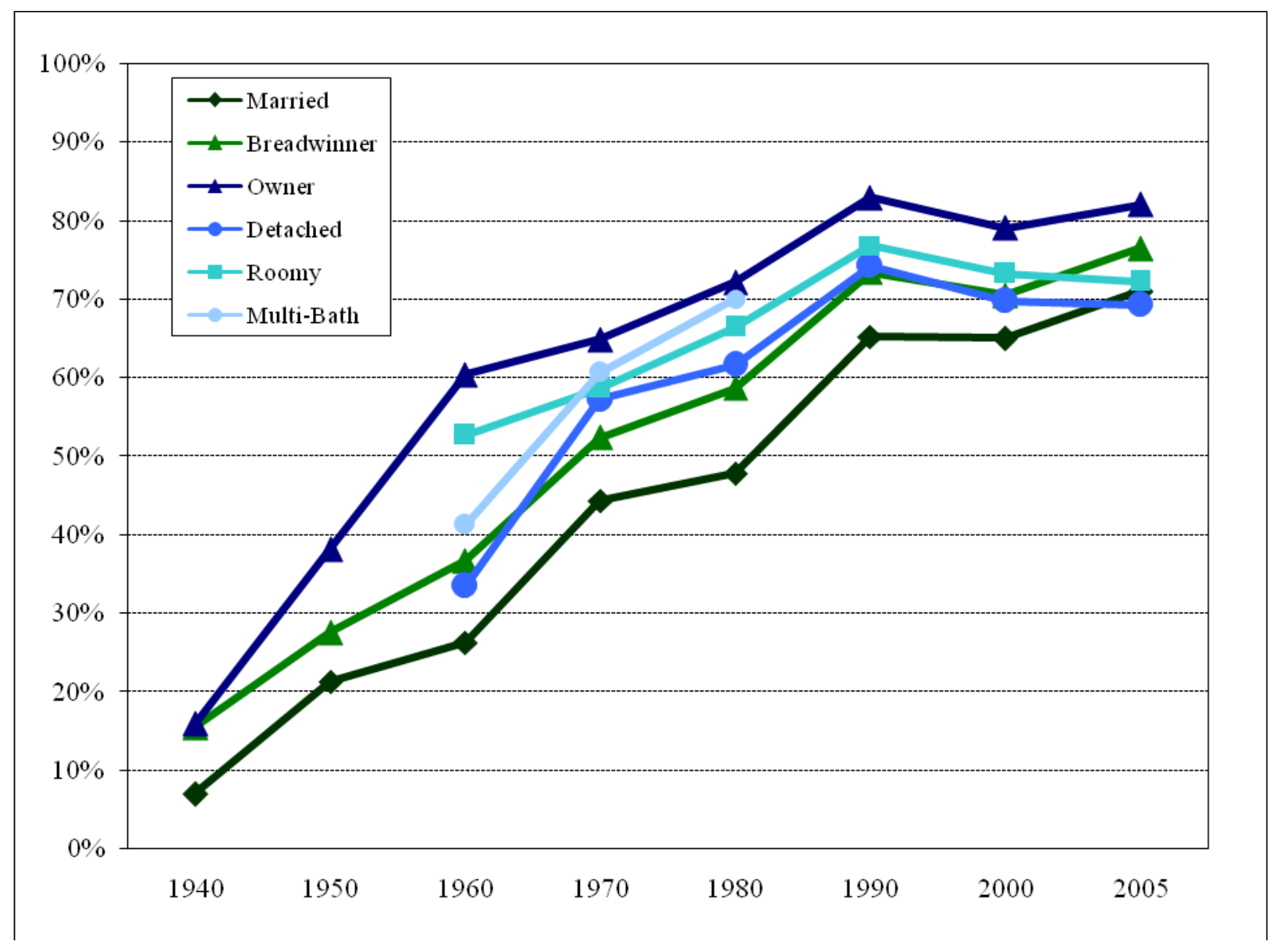


Lauster Housing and the Proper Performance of American Motherhood, 1940-2005

Chart Two. Access to Home Ownership by Year and Income Source, Non-Hispanic White Women Age $15-45$.

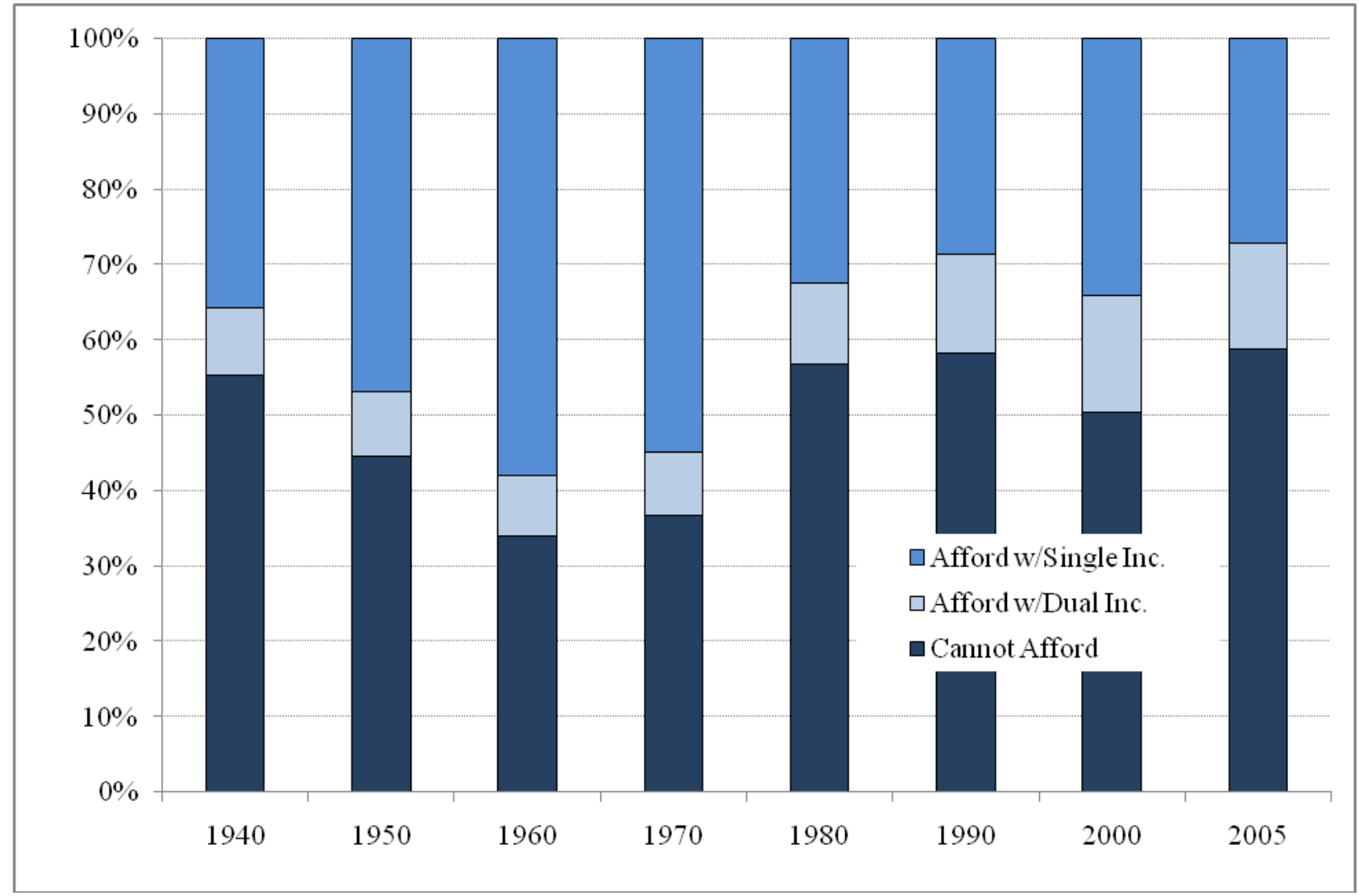


Lauster Housing and the Proper Performance of American Motherhood, 1940-2005

Chart Three. Access to Ownership and Actual Ownership by Year and Income Source, Non-Hispanic White Women Age 15-45

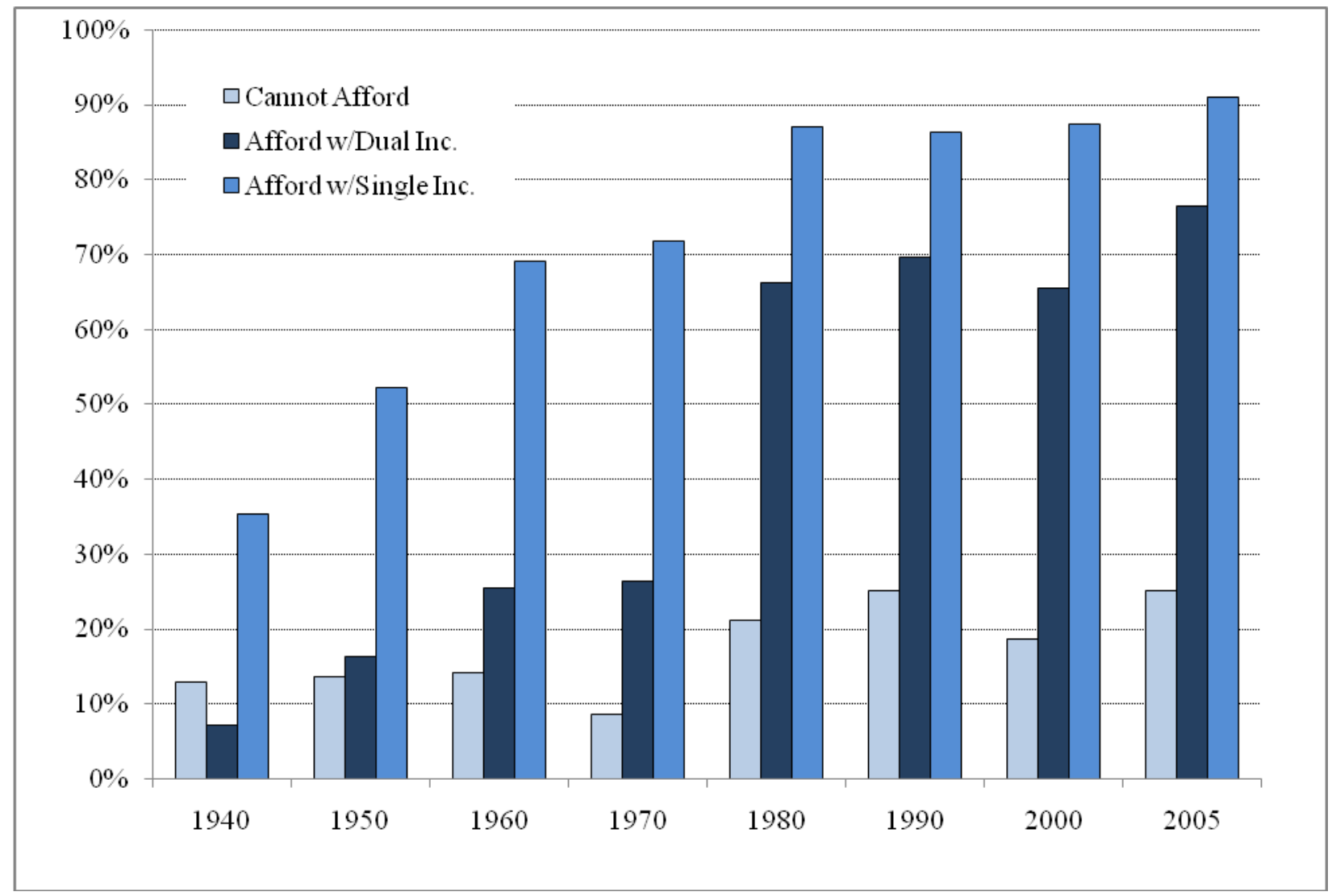


Lauster Housing and the Proper Performance of American Motherhood, 1940-2005

Chart Four. Estimated TFR and Stage Readiness of Women, Non-Hispanic White Women Age 15-45

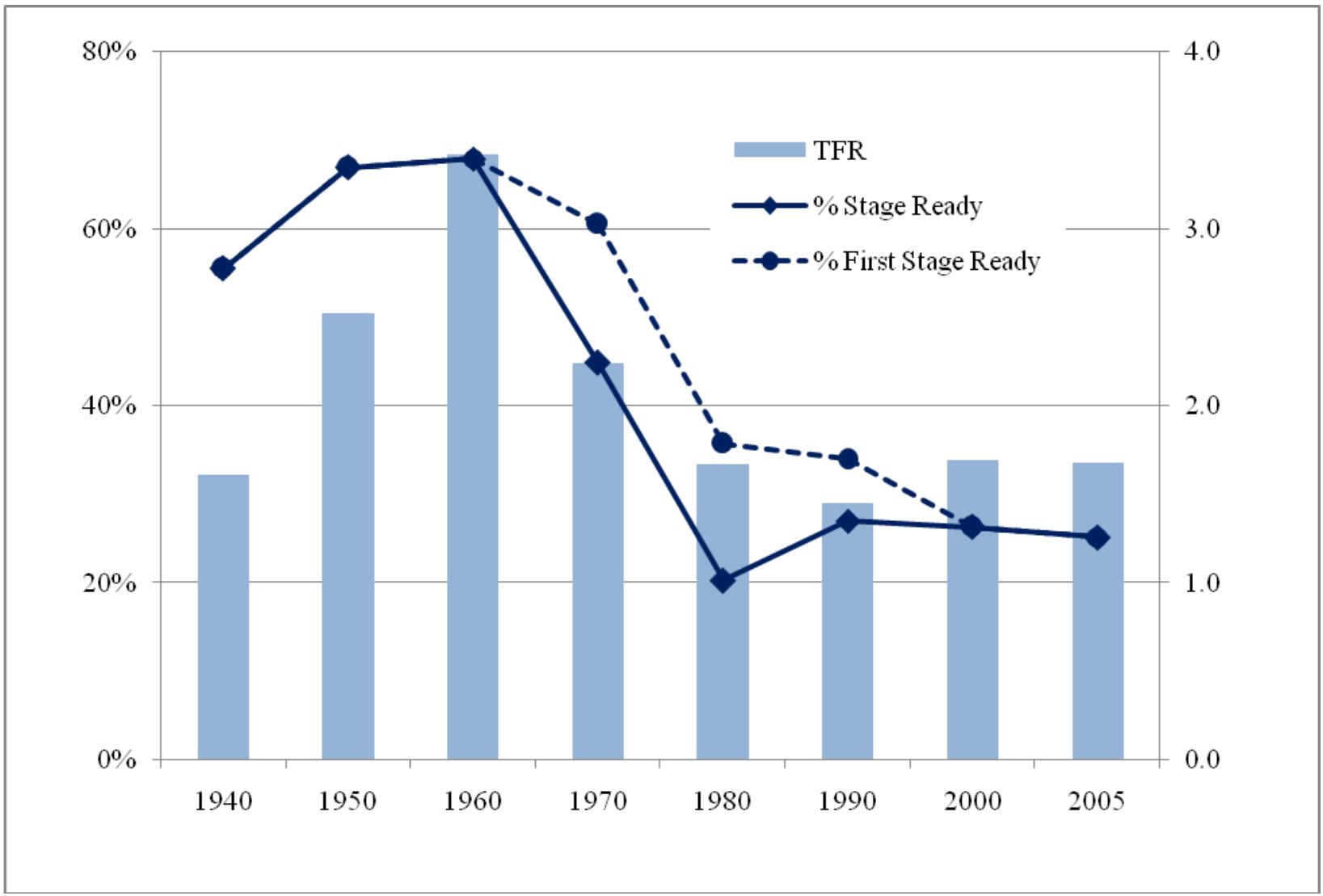


Lauster Housing and the Proper Performance of American Motherhood, 1940-2005

Chart Five. Estimated TFR by Stage Readiness, and Estimated Average Number of Years Stage Ready for Non-Hispanic White Women Age 15-45

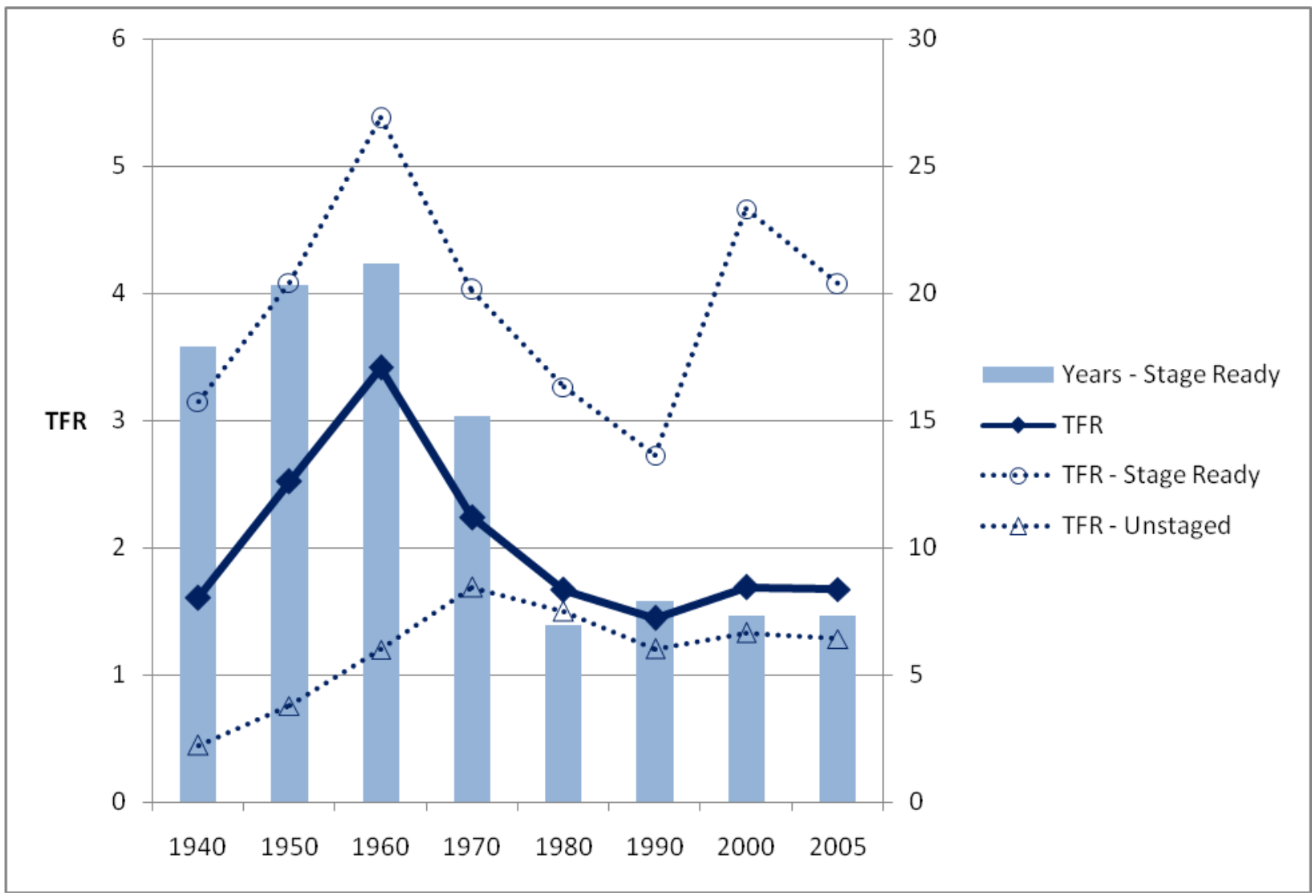


Lauster Housing and the Proper Performance of American Motherhood, 1940-2005

Chart Six. Estimated Average Numbers of Years Spent by Motherhood and Stage Readiness Categories, Non-Hispanic White Women Age 15-45

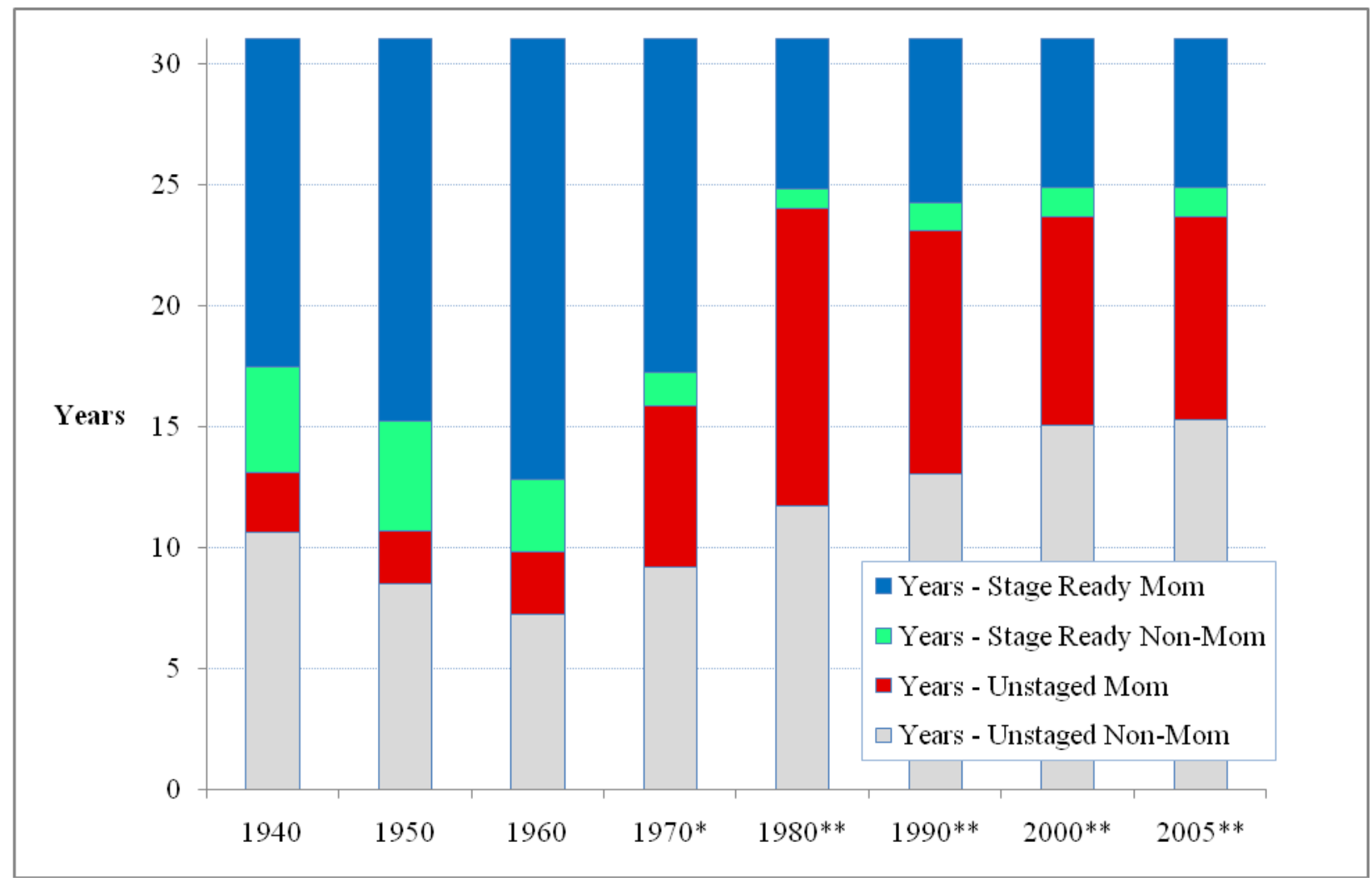

